\title{
Högre utbildning och hållbar omställning - En reflektion över studenternas roll
}

\author{
John Holmberg \\ Avdelningen för fysisk resursteori, Chalmers tekniska högskola
}

\begin{abstract}
För att klara de globala utmaningarna menar FN:s Agenda 2030 att det krävs omställning av samhälleliga system. Det räcker inte med marginella justeringar. Ohållbara transport-, energi-, mat- och sjukvårdsystem behöver fasas ut och ersättas med hållbara. För att klara dessa omställningar behövs helhetssyn och samverkan. I denna artikel ger jag min reflektion över FN:s process för lärande för hållbar utveckling och på vilket sätt högskolor och universitet (HoU) kan bli mer aktiva i denna hållbarhetsomställning genom att ta vara på studenternas unika roll som möjliggörare.
\end{abstract}

Nyckelord: Lärande, hållbar utveckling, systeminnovation, expedition, ledarskap

\section{FN:S ÅRTIONDE FÖR LÄRANDE FÖR HÅLLBAR UTVECKLING}

Den internationella uppslutningen för att skapa FN:s årtionde för lärande för hållbar utveckling (The United Nation Decade of Education for Sustainable Development DESD) startade vid FN:s världskonferens i Johannesburg 2002. Detta var till del en reaktion på att lärande för hållbar utveckling (ESD) inte var prioriterat vid FN:s världskonferens i Rio 1992 (även om det i kapitel 36 av Agenda 2I framgår att det finns ett behov att utveckla nationella strategier för ESD som ett första steg). I december samma år beslutade FN:s generalförsamling om att införa DESD mellan 2005-20I4 och UNESCO gavs ansvaret att leda arbetet.

Det var många av oss som var med i Johannesburg 2002 som överraskades av att Sveriges dåvarande statsminister, Göran Persson, bjöd in till ett internationellt rådslag om lärande för hållbar utveckling. Rådslaget ägde rum i Göteborg 2004, då representanter från 70 länder och tre svenska ministrar närvarade.

Rektorerna för Chalmers tekniska högskola och Göteborgs universitet bestämde sig för att följa upp rådslaget med att förbereda för en bra start av DESD och nästa internationella konferens. Tillsammans startade de två universiteten en process tillsammans med UNESCO. Där bjöds internationella experter in för att ge sin syn på hinder och möjligheter för ESD inom högre utbildning, den traditionella skolan, förskolan samt i det informella lärandet utanför skolsystemet. Detta arbete resulterade i fyra UNESCO-rapporter och en gemensam deklaration. När det gäller drivkrafter och barriärer för arbetet med ESD i högre utbildning är dessvärre många av insikterna som de $3 \mathrm{I}$ internationella experterna presenterade i rapporten fortfarande aktuella (Holmberg \& Samuelsson, 2006).

Processen involverade, som nämndes ovan, alla stadier av utbildningsnivåer. Wals och Corcoran (2006) återväckte frågan: ”Vad gör högre utbildning högre än annan utbildning?”

*Författarkontakt: John Holmberg, john.holmberg@chalmers.se

Artiklar och reflektioner är kollegialt granskade. Övriga bidragstyper granskas av redaktionen. Se https://hogreutbildning.se ISSN 2000-7558

(C)2020 John Holmberg. This is an Open Access article distributed under the terms of the Creative Commons Attribution-NonCommercial 4.0 International License (https://creativecommons.org/licenses/by-nc/4.0/), allowing third parties to share their work (copy, distribute, transmit) and to adapt it, under the condition that the authors are given credit, that the work is not used for commercial purposes, and that in the event of reuse or distribution, the terms of this license are made clear.

Citation: Holmberg, J. (2020). "Högre utbildning och hållbar omställning - En reflektion över studenternas roll», Högre utbildning, 10(1), 90-97. https://doi.org/10.23865/hu.v10.2424 
Det kan ifrågasättas om kvalifikationen "högre" har att göra med kvaliteten i lärandet som äger rum i högre utbildning. Högre utbildning är till stor del fortfarande fast i ett förhållningssätt som är envägs, hierarkiskt och reproduktivt i förhållande till lärandet och innehållet är ofta disciplinärt uppdelat med bristande helhetsperspektiv. Ironiskt nog verkar utbildningar bli allt mer verklighetsorienterade och experimenterande ju längre ner man går i utbildningssystemet. Fulgham (1986) skrev att visdom inte hittas på toppen av forskarutbildningen utan i sandlådan. Han illustrerar det i sin berömda bok All I Ever Needed to Know I Learned in Kindergarten, i vilken han gav en rad exempel: dela med dig; ta inte saker som inte är dina; slåss inte; lek schyst, städa efter dig; be om förlåt om du gör någon illa; tvätta händerna innan du äter; håll handen när du går över gatan ... Wals och Corcoran (2006) menar att sådana insikter har stark koppling till hållbar utveckling och att utbildningsystemet verkar erodera insikterna från förskolan när vi klättrar uppför utbildningsstegen och att våra utbildningsprocesser och -miljöer i högre utbildning behöver bli mer autentiska, inspirerande och drivna av existentiella frågor.

Regeringsskiftet 2006 innebar att tillträdande utbildningsminister inte ville att Sverige skulle driva ESD-frågan vidare internationellt. Hållbar utveckling ansågs vara förra regeringens fråga. $\mathrm{Nu}$ är det klimat som gäller! Därmed gick luften ur den svenska processen och Sverige lämnade över förarbeten och stafettpinnen till Tyskland, som stod värd för DESD:s halvvägskonferens i 2009 och till Japan att vara värd för DESD:s avslutande konferens 20I4. Det är när de långsiktiga och globala frågorna som hållbar utveckling hanteras kortsiktigt i fyraåriga mandatperioder på nationell nivå som man ändå gläds över de tröga systemen på FN-nivå. I FN-systemet finns minnet kvar liksom det internationella ansvarstagandet ända tillbaks till förklaringen av de mänskliga rättigheterna 1948 .

Jag fick förtroendet att ingå i den internationella referensgruppen till DESD. Gruppens roll var att tänka strategiskt om vad UNESCO kan och bör göra samt stärka arbetet med att engagera partner (UNESCO, 2007). Komplexiteten i hållbarhetsfrågan blev tydlig redan vid gruppens första möte i Paris i oktober 2006. Medan klimatfrågan stod högt på dagordningen $\mathrm{i}$ västvärlden, var frågan om hur man håller ihop en nation med många olika trosuppfattningar en viktig fråga i Indien, världens största demokrati. I många av de afrikanska länderna var HIV den viktigaste frågan. Jag upplevde en stor diskrepans mellan den komplexitet, vidd och betydelse med vilken man behandlade hållbar utveckling vid dessa möten, jämfört med hur frågan behandlades av de flesta ledningar vid HoU. I UKÄ:s utvärdering av hållbarhetsarbetet $\mathrm{i}$ landets HoU konstaterades att två tredjedelar ännu inte arbetar systematiskt med uppföljning och utveckling av hållbar utveckling i utbildningen (UKÄ, 20I7). Detta är anmärkningsvärt när Sverige har haft en förordning i högskolelagen ända sedan 2005 som ger universitet och högskolor ett särskilt uppdrag att främja hållbar utveckling i sin verksamhet (SFS, 1992).

Redan innan DESD avslutades beslutade UNESCO:s medlemsländer att låta arbetet med lärande för hållbar utveckling fortsätta genom "Global Action Programme on Education for Sustainable Developmant" (GAP) med fem prioriterade områden:

I) Utveckla policy

2) Förändra (eng. transform) lärandemiljöer

3) Kompetensutveckla lärare och utbildare

4) Stärka, mobilisera och synliggöra ungdomars viktiga roll och engagemang

5) Engagera medborgare, lokalsamhällen och kommuner i utbildning för hållbar utveckling (UNESCO, 20I4b). 


\section{John Holmberg}

Vid UNESCO:s avslutande världskonferens för DESD i Aichi-Nagoya 2014 hade jag rollen som rapportör för högre utbildning. Mycket är fångat i den slutliga rapporten för årtiondet: "Shaping the future we want" (UNESCO, 20I4a). Jag vill dock lyfta en fråga som vi hela tiden kom tillbaks till: "Behöver HoU uppdatera sitt övergripande uppdrag?" Tidigare i historien har $\mathrm{HoU}$ reagerat på samhällsförändringar och ändrat sitt uppdrag. Platons akademi (387 f.Kr.) stod modell för de första universiteten i Bologna (IO80) och Paris (II5O), dessa svarade på ett utbildningsbehov kopplat till den katolska kyrkan. Långt senare förde upplysningen med sig det disciplinbaserade forskningsuniversitetet med start i Berlin (I8IO). På senare tid har idén om den kunskapsbaserade ekonomin inneburit att universiteten ska bidra till utveckling. Förslaget som framfördes i Aichi-Nagoya 20I4 var att detta uppdrag bör revideras till att gälla hållbar utveckling snarare än utveckling i allmänhet. Motsvarande tankar har framförts tidigare i litteraturen (Cortese, 2003; Trencher et al., 20I4; Orr, 1994). Hur kan man då förstå hållbar utveckling som det nya uppdraget för HoU? Kan FN:s Agenda 2030 ge oss ledtrådar?

\section{FN:S AGENDA 2030}

När Agenda 2030 lanserades i New York, 26 september 2015, hade aldrig någonsin tidigare så många regeringsföreträdare varit samlade på samma plats. Det var tydligt att Agenda 2030 var efterlängtad och togs på allvar. Processen som låg bakom agendan var också mycket bredare och omfattande än den process som låg bakom de milleniemål som ersattes. Dessutom riktar sig de I7 hållbarhetsmålen till både globala nord och globala syd medan 7 av de 8 milleniemålen riktade sig främst till globala syd. Nu skulle världen mobiliseras för en hållbar utveckling. Frågan lyftes till statsministernivå och alla dimensioner av hållbarhet skulle beaktas.

De 17 hållbarhetsmålen har fått en stor genomslagskraft. Att den svenske grafiske designern Jakob Trollbäck lyckades sammanfatta svårtillgängliga texter till I7 slagkraftiga korta uttryck har varit en viktig del i spridningen. Han berättade vid ett möte för den svenska delegationen i samband med FN:s högnivåmöte 2017 om vilken märklig känsla det innebär att det är hans formuleringar som nu snurrar runt i världen. (Han berättade också hur svårt det var att hitta I7 unika färger som funkar ihop.) Samtidigt som de I7 färgglada målen har haft stor betydelse för spridningen finns det också risker med att närma sig Agenda 2030 enbart genom dem. Vid ett av de förberedande expertmötena i FN-skrapan (27-29 maj 2015) varnade chefen för FN:s kontor för hållbar utveckling, Nikhil Seth, för att läsa de 17 målen separerade från varandra - de hänger alla ihop. De får inte bli en checklista! Agenda 2030 innehåller också en text (United Nations, 20I5), som ger en bra vägledning om vilken genomgripande förändring som krävs. Tre nyckelord kan utläsas ur texten: transformation (omställning), integration (samverkan) och universalitet. Mycket av samtalet innan lanseringen av Agenda 2030 handlade om hur innebörden av dessa ord skulle förmedlas och diskuteras på bästa sätt.

Ordet transformation (omställning) är centralt i Agenda 2030 som också har namnet "transforming our world" (United Nations, 20I5). Insikten ökar på olika håll i samhället om att marginella förändringar inom rådande system och strukturer inte förmår att hantera de stora samhällsutmaningarna. Ska vi klara klimatutmaningen, sociala orättvisor och garantera hälsa i framtiden behöver vi förändra hela system. Transformation av system möter naturligtvis stort motstånd eftersom t.ex. rådande sociotekniska system är inlåsta i rådande kunskaps-, teknik-, marknads-, policy- och normstrukturer (Markard m.fl., 20I2). Ofta är vi också själva en del av systemet som behöver förändras. Att fortsätta att göra det vi gör ännu kraftfullare eller smartare kommer troligen inte att leda till systemförändring. Verklig förändring börjar med insikten om att vi är en del av systemet som vi vill förändra. 
Ordet integration är också centralt och handlar om integrering av perspektiv och aktörer.

När vi arbetar med systemförändringar behöver olika perspektiv integreras. Vi kan till exempel inte först fokusera på klimataspekter när transportsystemet ställs om och därefter ta hänsyn till social rättvisa. Vi behöver ha alla relevanta perspektiv integrerade i arbetet från början. Detta är en utmaning eftersom vår vana är att dela upp problem i delar och lösa delarna. Perspektivmedvetenhet är alltså en viktig strävan i omställningsprocesser (Jordan, 20II). Inte minst insikten om att vi inte beskriver världen vi ser, utan ser världen vi beskriver (Bohm, 2002).

Ingen enskild aktör har rådighet över en systemomställning, som därför ofta kräver nya former av samverkan. Det behövs alltså även en integration av olika aktörsgrupper i arbetet. Detta är en utmaning eftersom vi under lång tid har byggt silostrukturer inom och mellan organisationer. Lösningen är ofta att sätta frågan i centrum och bjuda in personer från berörda aktörsgrupper. Men vem definierar frågan, vem bjuder in och får till en konstruktiv process som löper över våra inarbetade silostrukturer?

Om idén är att medskapa i komplexa system med stor osäkerhet finns det en stor poäng att sätta lärandet i centrum. Finns tilliten vågar man experimentera och även lära av misstag, eller som Nelson Mandela sa: "I never lose. I either win or learn.” Det handlar till stor del om att medvetet skapa ett rum (utrymme) för förändring och att på ett neutralt och respektfullt sätt engagera människor i äkta frågor utan en dold agenda. Det skapar en helt annan energi än att försöka få människor att ansluta sig till en fördefinierad plan.

Det tredje nyckelordet, universalitet, handlar om att det inte räcker att finna lokala lösningar. Dessa måste även kunna fungera i ett globalt sammanhang. De flesta av de stora samhällsutmaningarna är globala i sin karaktär, vilket innebär att om lokala lösningar ska vara hållbara måste de vara del av de globala lösningarna. Agenda 2030 uttrycker universalitet kraftfullt med orden "Leave no one behind".

Under konferensen "Education as a driver for the SDGs", som var den första konferensen som anordnades (i Ahmebadad, jan 20I6) kopplat till den nya Agenda 2030, var det självklart att lärande som fenomen är en förutsättning och möjliggörare för alla de 17 globala målen. Det blir för snävt att tänka att lärande för hållbar utveckling ska rymmas under mål nummer 4 . Att HoU kan spela en mycket viktig roll för hela Agenda 2030 var också temat för ett seminarium som anordnades av Higher Education Sustainability Initiative (HESI), "higher education institutions - key driver of the sustainable development goals" under FN:s högnivåmöte 2017. Hållbar utveckling är i grunden en stor samhällelig lärandeprocess.

\section{HOU:S BIDRAG TILL HÅLLBAR UTVECKLING}

Om vi ska fånga den fråga som väcktes i inledning av texten, "behöver HoU uppdatera sitt övergripande uppdrag?”, krävs troligen lärande på flera nivåer (Bateson, 1972). Frågan berör det som har föreslagits som en förståelse av trippel-loop-lärande, vilket innebär att verksamhetens övergripande syfte och det system som verksamheten råder under undersöks och ändras (Tosey m.fl., 2012).

I resonemangen nedan kommer jag att fokusera på det extra som hållbar omställning kan innebära för HoU. Det innebär inte att annat som redan görs vid $\mathrm{HoU}$ inte längre är viktigt. Det innebär att HoU måste svara upp mot ytterligare en önskan i samhället och därmed addera några arbetssätt och kanske ändra andra. På samma sätt som HoU alltid har gjort vid tidigare historiska skiften (se ovan): från utbildningsfokus i skiftet till forskningsfokus (med bibehållen men delvis ändrad utbildning); till svar på kunskapssamhällets önskan om HoU:s bidrag till utveckling (med bibehållen men delvis ändrad utbildning och forskning); till att nu svara på 


\section{John Holmberg}

världssamhällets önskan om bidrag till hållbar omställning (med allt annat bibehållet och delvis ändrat). Frågan är alltså vad som bör ändras i skiftet till att bidra till hållbar omställning. I resterande del av denna text försöker jag exemplifiera vad ovanstående resonemang kan betyda för $\mathrm{HoU}$ i praktiken med speciellt fokus på vilken viktig roll studenterna kan spela. Jag kommer huvudsakligen att använda mig av exempel som jag själv har varit involverad i, i min roll som lärare, forskare och vicerektor vid Chalmers.

HoU:s viktigaste uppgift är att ge studenterna relevanta kunskaper, kompetenser och förmågor för framtiden. Att alla studenter ska få grundläggande insikter om hållbar utveckling och möjligheter att fördjupa sig börjar bli en självklarhet inom HoU. Ofta sträcker sig dock inte dessa kurser längre än att de ger studenterna ytterligare insikter i hur illa det är ställt. För att ge studenterna förmågor att arbeta transformativt och integrativt med samhällets utmaningar behöver undervisningsformerna ses över. Studenterna behöver ges utrymme för att tränas i förmågan att förstå system från flera perspektiv och att ställa bra frågor (inte bara hitta svar på givna frågor), samverka över ämnesgränser och med andra samhällsaktörer samt att utveckla hållbarhetsdrivna entreprenörsförmågor. En viktig utgångspunkt är att HoU börjar se på studenterna med nya ögon. Inte som kärl som ska fyllas med kunskap utan som de viktiga samhällsaktörer de faktiskt är. Få andra är så nyfikna, drivna och öppna för nya gränsöverskridande samarbeten! Eftersom de inte representerar några andra än sig själva och genom att alla vet vad en student är, har de flesta aktörer en öppen attityd till studenter. Studenterna representerar därför i sig själva en transformerande och integrerande kraft. När det gäller HoU:s förmåga att ta till vara studenternas kraft finns det riktigt mycket att göra!

I Daniella Tilburys expertgranskning av processer och lärande kopplat till DESD (Tilbury, 20II) konstateras att även om det finns mycket information om specifika mål och resultat från ESD-projekt, så finns det anmärkningsvärt få data som visar hur dessa mål och resultat har åstadkommits. Fältet är fortfarande undermåligt beforskat. Hon menar också att för framgångsrikt lärande för hållbarutveckling verkar det sammantaget vara viktigt med ett aktivt och deltagande lärande med verkliga (icke-konstruerade) utmaningar. Gärna i lärandesituationer där flera intressegrupper och perspektiv möts i samverkan och dialog. Hon pekar vidare på att detta ofta kräver förnyelse av läroplaner och vidareutbildning av lärare på ett betydligt djupare plan än att tillhandahålla resurser och verktygslådor. Motsvarande insikter lyfts också i GAP samt av andra forskare inom fältet, t.ex. Wals (2009). Söderberg (2017, s. 85) skriver i ett tidigare nummer av denna tidskrift: "Ett problem som jag ser är att vi ofta arbetar med låtsade problem. Då möter vi inte verklighetens oförutsägbarhet, intressekonflikter och komplexitet, och då får studenterna inte heller öva på att ställas inför situationer där deras värderingar aktiveras ...”

När det gäller Chalmers arbete med utbildning för hållbar utveckling finns det mycket att säga, och mycket är också beskrivet, se t.ex. Holmberg m.fl. (20I2). Jag vill dock lyfta en lärdom från det tidiga arbetet som också har relevans för omställningsarbete i allmänhet. Chalmers har arbetat med obligatoriska kurser i miljö och senare hållbar utveckling för alla studenter sedan 1985. När ESD-projektet drog igång 2006 ville vi bland annat göra en kraftsamling för att integrera hållbar utveckling i existerande kurser. Vi gjorde en föreläsningsturné till de olika institutionerna för att försöka övertyga lärare om poängen med detta. Det gick dåligt! - "teachers hate to be taught". Vi ändrade därför strategi helt. Vi byggde en grupp av personer som både var insatta i lärande för hållbar utveckling och hade ämneskunskap inom olika delar av Chalmers verksamhet. Strategin var nu att denna grupp skulle besöka lärare och intervjua dem och intressera sig för deras ämne. Genom att intervjua enskilda lärare och diskutera hur deras ämne kan relatera till hållbar utveckling och hur denna koppling kan tydliggöras, kände sig lärarna fortfarande i kontroll över 
sitt ämne och var därigenom mer öppna för förändringar och integrering av hållbar utveckling (Holmberg m.fl., 20I2). Att lyssna var alltså en kraftfullare förändringsstrategi än att försöka övertyga!

I Holmberg (2020) beskrivs hur Chalmers byggde en ny matrisorganisation med styrkeområden för att öka förmågan till samverkan och systeminnovation runt de stora samhällsutmaningarna. I samma text nämns även att det inte sällan brast i tillit mellan aktörer från olika verksamheter inom de olika regionala kunskapsklustren. Detta kändes väldigt tråkigt med tanke på vilket engagemang och tillit det fanns mellan samma aktörsgrupp på högsta nivå. Hur skulle tillit kunna byggas i regionen så att man är villig att samarbeta och kanske till med vågar göra misstag ihop? I detta skede drog jag mig till minnes vad studenter kan åstadkomma när det gäller tillitsbygge. Jag hade några år tidigare blivit bjuden till Barcelona för att ge en kurs i hur man kan arbeta med backcasting i förändringsprocesser. Jag föreslog att vi skulle försöka hitta ett angeläget verkligt case att jobba med. Man valde vattenknapphet och bjöd in studenter från olika delar av världen för en tvåveckorskurs. Första veckan fick studenterna lära sig metoder och verktyg och andra veckan bjöds relevanta samhällsaktörer in från myndigheter, akademi och det privata näringslivet. Dessa aktörer fick inte hålla sin vanliga presentation, utan bjöds in att sitta $i$ en ring ihop med studenterna. Studenterna började sedan att fråga de inbjudna aktörerna om problembilden och aktörerna svarade ur sina olika perspektiv. Det var som att de ville studenterna väl, hade överseende med att frågorna inte alltid var "politiskt korrekta". De kände sig inte hotade av studenterna - garden var nere och ofta sade de att de hade berättat mer än vad de tänkt. Studenterna lyckades kartlägga "systemet" och hitta okända inlåsningar och möjligheter. Studenterna hade dessutom börjat bygga tillit mellan aktörer (som i flera fall inte hade träffats tidigare) och därigenom hade de startat processer som få andra aktörer i samhället skulle ha lyckats med - just för att de är studenter!

Utifrån denna erfarenhet skapade vi Challenge Lab - where learners lead and leaders learn (Holmberg, 20I4). Challenge Lab är ett initiativ där masterstudenter tar sig an hållbarhetsomställningar i samverkan med forskning, näringsliv och samhälle. Challenge Lab är en arena för utmaningsdriven systeminnovation och medskapande för en hållbar framtid. Studenterna kartlägger system ihop med relevanta aktörer och identifierar hävstångspunkter där en liten insats kan få stor påverkan för hållbar omställning. Ofta ligger dessa hävstångspunkter i mellanrummet mellan olika aktörer. Studenterna gör sedan sina examensarbeten med forskningsfrågorna i dessa hävstångspunkter och tar därigenom ägarskap för "mellanrumsfrågorna" för en tid. Inte sällan leder detta till att frågorna senare hittar sitt ägarskap hos någon samhällelig aktör eller blir starten för en ny verksamhet.

Challenge Lab har funnits i 7 år och består av en förberedande kurs "Leadership for sustainability transitions" (och från i höst även kursen "Systems interventions for sustainability transitions") samt ett laboratorium för examensarbeten som samlar studenter med olika utbildningsbakgrund. Vi har tidigare sett att denna undervisningsform skapar värde för studenter, forskare och samhälle (Larsson \& Holmberg, 20I8). I djupare utvärderingar lyfter studenterna fram värdet av att få jobba med verkliga komplexa hållbarhetsutmaningar i samhället tillsammans med samhällsaktörer, att bli vägledda av en strukturerad metodik för att förankra hållbarhetsutmaningar i ett systemperspektiv i riktning mot hållbarhet och att få utrymme att utforska och bygga ledarskapsförmågor utifrån sina egna värderingar och förutsättningar "inifrån och ut" (Holmén m.fl., kommande).

Utöver att denna undervisningsform ger betydliga mervärden för studenternas lärande och motivation kan den också ge mervärden till HoU:s övriga roller. Inom forskning kan vi se att 
studenterna kan förbereda för transdisciplinär forskning genom att investera tid (som ofta är hindret för forskare) i frågeställningar som kopplar HoU med externa aktörer. Reality Studies i Kisumu i Kenya är ett lysande exempel på detta. Genom att studenterna kartlägger system innan de bestämmer forskningsfråga har de även kunnat hitta frågor som har legat i mellanrummet internt inom en forskningsavdelning. Inom HoU:s nyttiggörande, innovation och externa samverkan har vi sett hur studenternas kartläggning av system och vilja att för en tid ta ägarskap för frågor i mellanrummet har lett till nya processer för regional samverkan mellan HoU och externa aktörer. Exempel på sådana exjobb gäller elektromobilitet i Göteborg, stadsodling i Göteborg och klimatarbetet i Västsverige. I december 2019 beslutade regionutvecklingsnämnden i Västra Götalandsregionen att ge ett stort anslag för spridningen av Challenge Lab i regionen i syfte att "möjliggöra träning för universitetsstudenter i kompetenser för att lösa komplexa samhällsutmaningar med systeminnovation, samtidigt som relationer mellan regionala aktörer stärks och bidrar till regionens utveckling". Även inom HoU:s interna campusutveckling kan studenterna göra stora bidrag. Exempelvis samlar studenterna i kursen "Leadership for sustainability transitions" aktörer från olika verksamheter på Chalmers campus för att hitta förändringsmöjligheter, vilket resulterar i ca Io genomarbetade förändringsförslag varje år.

Tilbury (2016, s. 274) skriver: "Genuine student engagement is hard to practice across a system that currently regards students as recipients rather than co-creators of knowledge" och i slutrapporten för FN:s årtionde (UNESCO, 20I4a, s. 177) för lärande för hållbar utveckling, konstateras: "Build capacity for working in partnership and facilitating multi-stakeholder, social learning. Educators and trainers play an important role in catalyzing, linking and mediating interaction within multi-stakeholder mechanisms. Capacity-building for the facilitation of learning through partnerships ... will be essential in the years to come."

Internationellt kan vi se en trend av allt fler lärandemiljöer motsvarande Challenge Lab och hur erfarenheter och idéer sprids till den ordinarie utbildningen. Dessa lärandemiljöer, inklusive Challenge Lab, är naturligtvis inte färdigutvecklade. Det kommer dessutom att komma många nya spännande lärarmiljöer att inspireras av. Vi är bara i början av resan att ta studenterna på större allvar och bjuda in dem att göra hela HoU-sektorn mer relevant för hållbar omställning! Vid samtal med motsvarande initiativ runt om i världen framgår att det största hindret för denna utveckling är inlåsta utbildningssystem och brist på insiktsfullt och modigt ledarskap, vilket också var en viktig slutsats för DESD (UNESCO, 20I4a). I Holmberg (2020) ger jag en reflektion över ledarskapskompetenser i undervisningen och ledarskapets betydelse inom undervisningsorganisationen för att möjliggöra för studenter att bygga sådana kompetenser samtidigt som de skapar värde för andra.

\section{FÖRFATTARPRESENTATION}

John Holmberg är professor i fysisk resursteori, innehavare av en UNESCO-professur i lärande för hållbar utveckling och grundare av Challenge Lab vid Chalmers tekniska högskola.

\section{REFERENSER}

Bateson, G. (1972). Steps to an Ecology of Mind. San Francisco: Chandler Pub. Co. Bohm, D. (2002). Wholeness and the implicate order. London; New York: Routledge.

Cortese, A. D. (2003). The Critical Role of Higher Education in Creating a Sustainable Future. 8. Fulgham, R. (1986). All I need to know, I learned in kindergarten. New York: Ivy Books.

Holmberg, J. (2014). Transformative learning and leadership for a sustainable future: Challenge Lab at Chalmers University of Technology. I P. B. Corcoran, B. P. Hollingshead, H. Lotz-Sisitka, A. E. J. 
Wals \& J. P. Weakland (red.), Intergenerational learning and transformative leadership for sustainable futures (s. 91-102). Wageningen Academic Publishers. https://doi.org/10.3920/978-90-8686-802$5 \_4$

Holmberg, J. (2020). Ledarskap för hållbar omställning i högre utbildning. Högre utbildning, 10(1), 98-107.

Holmberg, J. \& Samuelsson, B. E. (red.). (2006). Drivers and Barriers for Implementing Sustainable Development in Higher Education. UNESCO Education sector.

Holmberg, J., Lundqvist, U., Svanström, M. \& Arehag, M. (2012). The university and transformation towards sustainability: The strategy used at Chalmers University of Technology. International Journal of Sustainability in Higher Education, 13(3), 219-231. https://doi.org/10.1108/14676371211242544

Holmén, J., Adawi, T. \& Holmberg, J. (kommande). Student-led sustainability transformations: Mechanisms of learning in a 'Challenge Lab' curriculum methodology.

Jordan, T. (2011). Skillful Engagement with Wicked Issues-A Framework for Analysing the Meaning-making Structures of Societal Change Agents. Integral Review: A Transdis- ciplinary and Transcultural Journal for New Thought, Research, and Praxis, 7(2), 47-91.

Larsson, J. \& Holmberg, J. (2018). Learning while creating value for sustainability transitions: The case of Challenge Lab at Chalmers University of Technology. Journal of Cleaner Production, 172, 44114420. https://doi.org/10.1016/j.jclepro.2017.03.072

Markard, J., Raven, R. \& Truffer, B. (2012). Sustainability transitions: An emerging field of research and its prospects. Research Policy, 41(6), 955-967. https://doi.org/10.1016/j.respol.2012.02.013

Orr, D. (1994). Earth in Mind: On Education, Environment, and the Human Prospect. Washington, DC: Island Press.

SFS. (1992). 1434. Högskolelagen.

Söderberg, M. W. (2017). Kritisk självreflektion i komplexa frågor: Att hjälpa studenterna att ta makten över sitt tänkande. Högre utbildning, 7(2). https://doi.org/10.23865/hu.v7.1024

Tilbury, D. (2011). Education for sustainable development: An expert review of processes and learning. UNESCO Education sector.

Tilbury, D. (2016). Student engagement and leadership in higher education for sustainability. I M. Barth, G. Michelsen, M. Rieckmann \& I. Thomas (red.), Routledge Handbook of Higher Education for Sustainable Development (s. 241-260). Routledge: London and New York.

Tosey, P., Visser, M. \& Saunders, M. N. (2012). The origins and conceptualizations of 'triple-loop' learning: A critical review. Management Learning, 43(3), 291-307. https://doi.org/10.1177/1350507611426239

Trencher, G., Yarime, M., McCormick, K. B., Doll, C. N. H. \& Kraines, S. B. (2014). Beyond the third mission: Exploring the emerging university function of co-creation for sustainability. Science and Public Policy, 41(2), 151-179. https://doi.org/10.1093/scipol/sct044

UKÄ. (2017). Universitets och högskolors arbete med att främja en hållbar utveckling. Rapport 2017:12.

UNESCO. (2007). The UN Decade of Education for Sustainable Development (DESD 2005-2014): The first two years; 2008. 64 .

UNESCO. (2014a). Shaping the Future We Want: UN Decade of Education for Sustainable Development (2005-2014): Final Report. http://unesdoc.unesco.org/images/0023/002301/230171e.pdf

UNESCO. (2014b). UNESCO roadmap for implementing the Global Action Programme on Education for Sustainable Development; 2014. 37.

United Nations. (2015). Transforming our world: The 2030 Agenda for Sustainable Development. United Nations.

Wals, A. (2009). Learning for a Sustainable World: Review of Contexts and Structures for Education for Sustainable Development. UNESCO Education sector.

Wals, A. \& Corcoran, P. B. (2006). Sustainability as an Outcome of Transformative Learning. I J. Holmberg $\&$ B. Samuelsson (red.), Drivers and Barriers for Implementing Sustainable Development in Higher Education. UNESCO Education sector. 